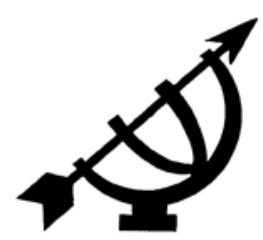

\title{
'n Prakties-teologiese ondersoek na die uitwerking van afwesige vaders: 'n verkennende kwalitatiewe ondersoek in die Promosa-gemeenskap
}

\author{
F.E. Freeks
}

Fakulteit Gesondheidswetenskappe

Potchefstroomkampus

Noordwes-Universiteit

POTCHEFSTROOM

E-pos: Fazel.freeks@nwu.ac.za

\section{G.A. Lotter}

Fakulteit Teologie

Potchefstroomkampus

Noordwes-Universiteit

POTCHEFSTROOM

E-pos: George.lotter@nwu.ac.za

\begin{abstract}
A practical theological investigation into the effect of absent fathers: an exploratory qualitative investigation in the Promosa community

In this article it is shown that empirical research can be used to confirm important findings in literature studies about the understanding of absent fathers and the devastating consequences such as social problems, socio-economic problems and psychological problems. A literature study was done on the role of the father and all the relevant aspects are viewed in a broader context. The results obtained through a qualitative investigation of eight women from Promosa (Potchefstroom) as a focus group confirmed the trends found in the preliminary literary research. The outcomes may have important implications in the field of practical theology and pastoral guidance for absent fathers, the women involved with those fathers and fatherless children. Some guidelines are proposed towards an effort to help fathers to become more involved.
\end{abstract}




\section{Opsomming}

\section{'n Prakties-teologiese ondersoek na die uitwerking van afwesige vaders: 'n verkennende kwalitatiewe ondersoek in die Promosa-gemeenskap}

In hierdie artikel word aangetoon dat empiriese navorsing gebruik kan word om literatuurstudies oor die afwesige vader en die gevolge soos sosiale, sosio-ekonomiese en psigologiese probleme te bevestig. Daar is eers 'n literatuurstudie gedoen oor die rol van die vader waar die relevante aspekte in 'n breër konteks ondersoek word. Die bevindings van 'n kwalitatiewe ondersoek deur agt vroue van Promosa (Potchefstroom) as fokusgroep te gebruik, het die voorlopige resultate van die literatuurondersoek bevestig. Die uitkomste mag belangrike implikasies in die veld van praktiese teologie en pastorale begeleiding vir hierdie vroue en kinders van afwesige vaders inhou. Daar word ook riglyne voorgestel vir pogings om vaders meer betrokke te kry.

\section{Inleiding}

Die probleemstelling wat in hierdie artikel ondersoek word, is die pyn en lyding wat afwesige vaders veroorsaak soos waargeneem by 'n fokusgroep van vroue in die Promosa woongebied (Potchefstroom). Dit blyk uit hulle verhale, sienings, ervarings, persepsies en belewenisse met betrekking tot die afwesige vader. Die artikel begin met 'n literatuurondersoek oor die onderwerp en daarna word die probleem van afwesige vaders prakties ondersoek deur 'n empiriese ondersoek waarin die doel, teoretiese vertrekpunte rakende kwalitatiewe navorsing, metodologiese verantwoording, 'n beskrywing van die ondersoekgroep (in hierdie geval die fokusgroep van agt vroue), gevolg word deur die ondersoekresultate. Die empiriese ondersoek bevestig grootliks die sake wat vooraf in die literatuurstudie na vore gebring is. Hierdie navorsing mag belangrike implikasies inhou vir die praktiese teologie en die pastorale begeleiding van hierdie vroue en kinders van afwesige vaders. Die artikel word afgesluit met voorstelle vir die begeleiding van en hulp aan afwesige vaders.

\section{Literatuurondersoek}

Die huidige tydvak is een vol geweld, korrupsie en oneerlikheid en skep 'n wêreld wat kinders baie maklik kan beïnvloed om vol haat, woede en pyn te word en sodanig te leef (Williams, 2008:18). Een van die oorsake hiervan kan die verskynsel van afwesige vaders wees. Die tendens van afwesige vaders kom nie net in plaaslike gemeenskappe binne Suid-Afrika voor nie, maar wêreldwyd (Family 
life, 1998:1). Die probleem van die afwesige vader laat dikwels erge gevolge by 'n gemeenskap ontwikkel en deur die gemeenskap word 'n hele volk geaffekteer. Hierdie probleem het verskillende rampspoedige implikasies (Staples, 1999:103-111, 195-198; vgl. ook Lupton \& Barclay, 1997:12-17). Volgens die literatuur doen hierdie probleem hom veral voor in die swart gemeenskappe met swakker omstandighede (vgl. Family life, 1998:2). Daarom word daar dikwels by sulke gemeenskappe mislukte gesinslewens en onsuksesvolle vader-kindverhoudings as gevolg van afwesige vaders ondervind (Staples, 1999:32-35; vgl. ook Palkovitz, 2007:195). Baie vaders is afwesig as gevolg van die hoë egskeidingsyfer in Suid-Afrika. Navorsing het getoon dat kinders sonder vaders maklik beïnvloed word tot geweld (Anon., 1998:36). Studies het verder aangetoon dat veral seuns wat sonder 'n vader grootword, maklik by misdaad betrokke raak (Mandara et al., 2005:207-220).

Een van die redes waarom die samelewing in so ' $\mathrm{n}$ dilemma verkeer, is dus waarskynlik die leemte van vaders in die lewens van kinders. Daarom word daar in hierdie eeu 'n dringende beroep op vaders gedoen om hulle verantwoordelikheid as vaders deurgaans na te kom (Williams, 2008:18). Williams (2008) beweer verder dat jonger vaders onbelangrik raak in hulle kinders se lewens (op grond van hulle onbetrokkenheid) en dat daar 'n ernstige soektog in die hele wêreld is na aktiewe vaders wat betrokke is in hulle kinders se lewens. Hulle moet nie net daar wees vir die verskaffing van geld of finansiële bystand nie. Kinders wil meer kwaliteittyd saam met hulle vaders deurbring. Die vader se waarde moet dus nie net aan geldelike voorsiening gemeet word nie, maar aan die liefde en aandag wat hy aan sy gesin en kinders gee (Williams, 2008:18). Baie kinders is op 'n stadium in hulle lewens onseker en verward. Juis die vader se gehegtheid aan hulle en sy teenwoordigheid in die huis het tot gevolg dat hierdie kinders met hom kan identifiseer. Dit skep vir hierdie kinders 'n platform van sekerheid (Ford et al., 2008:284-299). Seuns soek ook die voorbeeld van 'n vader om eendag hulle rol van vaderskap te kan vervul (Goeke-Morey \& Cummings, 2007:221-225).

Volgens Seutter en Rovers (2004:43-49) het die afwesige vader, of soos hulle dit noem die "weak father", soms homoseksualiteit by kinders, veral by seuns tot gevolg. Dit kan 'n aanvegbare standpunt wees, maar die feit bly dat waar die vader-seunverhouding grootliks misluk, aspekte soos selfbeeld, waardes, gedrag en verhoudings met ander nie op 'n gesonde wyse vasgelê word nie. Vir die voor- 
koming van hierdie probleem meen Dickie et al. (2006:57-71) behoort juis die vader 'n positiewe invloed op die kinders uit te oefen.

Aan die ander kant meen Johnson (1993:303-305) dat die onbetrokke vader primêr vrees vir mislukking ervaar en sekondêr 'n onsekerheid ervaar as dit kom by sy bevoegheid op die gebied van versorging. Die afwesige vader se plek word deur die surrogaatvader ingeneem (wat enige betrokke manlike figuur kan wees, of 'n prominente vrou) en hierdie vervanging skep ernstige probleme soos verkeerde identifikasie (Olsen, 2007:174-196). Wat die dogters betref, veroorsaak vaderafwesigheid 'n leemte in hulle ontwikkeling in die huis. Dit geld veral die voorsiening van die nodige inligting ten opsigte van verhoudings soos die keuse van die regte maat, kuisheid, die nadeel van voorhuwelikse seks en dies meer. Seksuele ongebondenheid, onstabiele verhoudings en verwarring is juis van die algemene probleme wat voorkom as gevolg van hierdie afwesigheid (Grainger, 2004:133). Volgens Steyn (1993:74-76; vgl. ook Smit, 2004:101-120) is daar in Suid-Afrika veral die tendens dat baie vaders ver van die huis af gaan werk, byvoorbeeld by myne en industrieë. Alhoewel die vader geld huis toe stuur, bly hy nogtans afwesig en sou kinders 'n groter voordeel geniet het indien hulle vaders teenwoordig was (Vogel et al., 2006:189-209). 'n Verdere probleem wat Steyn (1993:76-77) rakende die afwesige vader aantoon, is die ontstaan van enkelouerskap omdat die vader permanent afwesig is. Hierdie neigings kan baie nadelig wees, volgens Nhlapo (1998:9), veral wat die voortbestaan van die gesin betref. In die geval waar die vader van die gesin vervreem is en tog toenadering tot die kinders soek, word hy in baie gevalle deur die moeder verhoed om sy vaderlike rol te vervul (Wall, 2007:52-76). Indien die vader nie betrokke is nie en ook nie effektief optree nie, kan die situasie ontwikkel dat dissipline, orde, stabiliteit en groei in die gesin ontbreek en daardeur kan die gesin nadelig beïnvloed word. Krampe en Newton (2006:159-190) voer juis aan dat die fisiese teenwoordigheid van die vader by die volwasse kind stabiliteit, verantwoordelikheid en volwassenheid meebring. Indien daar nie 'n manlike figuur in die huisgesin is nie, en die vrou vertolk die rol van 'n vaderfiguur, bly die soeke nog steeds na 'n vader (Barker, 2000:195).

Volgens Benghiat (2001:64) bring die gebrek aan 'n vaderrol 'n groot skuif na geëmansipeerdheid teweeg en hy meen ook dat veral seuns identifiseringsprobleme ondervind as gevolg van die afwesigheid van die vader. Volgens Olivier (1997:19-20) word onderskei tussen finansiële probleme wat armoede teweeg bring en sosiale probleme as gevolg van verminderde sosiale kontak en isolasie, 
benewens die reeds genoemde psigologiese probleme. Maatskaplike probleme kan tot verlaagde lewenstandaard lei en affektiewe probleme kan verlies aan emosionele sekuriteit, 'n gevoel van onsekerheid, bitterheid en self-twyfel inhou.

Campbell (1994:55-56) toon aan dat die groeiende faktor in die gesin die vroulike rol is. Hy meen verder dat dit vir die moeder baie moeilik is om sonder 'n vader jong seuns in 'n gesin op te voed en te dissiplineer. Campbell het navorsing onder jong seuns en hulle ouers (moeders) gedoen om vas te stel hoe 'n moeder in 'n gesin wat sonder 'n vader funksioneer, beheer kan uitoefen. Van die opnames toon dat die alleenmoeder misluk om jong seuns behoorlik te dissiplineer en te lei. Indien 'n vader teenwoordig was, sou daar 'n verskil kon gewees het. Van die respondente onder wie die navorsing gedoen is, het meegedeel dat die seuns nie notisie geneem het van hulle moeders nie, maar dat hulle definitief sou reageer wanneer daar 'n vaderfiguur teenwoordig was (Campbell, 1994:56; vgl. ook Freeks, 2004:101).

Dit is dus duidelik dat die afwesigheid van die vader geestelike sowel as fisiese implikasies vir 'n gesin het, wat enorme probleme kan teweeg bring. Wanneer ' $n$ vader nie teenwoordig is nie, het dit geestelike skade en gevolge by kinders. Hierdie kinders kan nie met God as Vader identifiseer nie, omdat hulle nie 'n verhouding met hulle fisiese vaders het nie. Hierdie kinders kan selfs sukkel om God hulle Vader te noem. Hulle kan nooit 'n parallel trek tussen hulle aardse vader en God nie. Die kinders het geen besef wat 'n aardse vader is en hoe hy behoort op te tree nie en daarom het hulle geen begrip wat ' $n$ Hemelse Vader is en wat Hy doen nie (Warren, 2005:53).

Indien daar teruggegaan word na die Skriftuurlike fundering van die gesin en die rol van die vader en die kinders binne die gesin, merk 'n mens dat ook hierdie faset baie duidelik in sowel die Ou as Nuwe Testament hanteer is.

Vanuit 'n Ou-Testamentiese hoek kan aangetoon word dat kindskap belangrik is binne die gesin om uiteindelik ook heen te wys na die totstandkoming van God se uitverkore volk (Waltke, 2001:109-192). Binne die Nuwe Testament word die Griekse woord oikos gebruik om die gesin (huishouding) aan te dui (Moxnes, 1997:21). Die huishouding bestaan uit die ouers, kinders en al die bybehorendes, waaronder ook slawe (Louw \& Nida, 1989:113, 181). Dit is binne daardie gesin en selfs groter entiteit waar kinders tuis behoort te wees en geborgenheid ervaar - iets wat baie kinders moet ontbeer, 
soos uit hierdie navorsing blyk. Die respek waarmee die Christendom in die eerste kerklike gemeenskap geag is (Köstenberger, 2003:275) dui ook op die besondere invloed vir vandag met betrekking tot die selfbeeld van kinders waar die ouers teenwoordig en aktief betrokke is.

Die Bybel identifiseer God as Vader wat in krisistye veral ingryp en die volk uithelp en verlos - net so moet die man as vader sy rol in tye van krisis volstaan en sy familie uit die situasie uithelp en verlos van die onaangenaamdheid wat in die huis ontstaan (Niskanen, 2006:397-407).

\section{Empiriese ondersoek}

Bogenoemde literatuurstudie word vervolgens "gekontroleer" en deur 'n empiriese ondersoek verryk om vas te stel of die resultate wat in die literatuurstudie genoem word, inderdaad ook in die praktyk sodanig manifesteer.

Alhoewel dit buite die skopus van hierdie artikel val om 'n volledige uiteensetting te gee van die rol van empiriese navorsing binne die praktiese teologie, is dit noodsaaklik om aan te toon dat die empiriese komponent belangrik is vir hierdie vakgebied en 'n integrale deel van enige prakties-teologiese navorsing is. Thomas (2008:47) gee ' $n$ breedvoerige uiteensetting van die belangrikheid van "an empirical approach to the theological issues" en hy verwys na die werk van Van der Ven $(1993 ; 1994)$ asook die stigting van die tydskrif Journal of empirical theology.

Die praktiese teologie behoort kennis te neem van die navorsingsresultate van ander vakwetenskappe. Dit behoort nie alleen van ander empiriese navorsing te weet nie, maar dit self ook te doen (vgl. Cartledge, 2003:15; Ballard \& Pritchard, 2001:16).

Volgens Heyns en Pieterse (1998:38) moet saam met die "teologiese oorlewering" ook 'n empiriese situasie-analise gedoen word om daardeur tot 'n prakties-teologiese teorie te kom. Praktiese teologie kan derhalwe nie in 'n lugleegte beoefen word nie, maar behoort in interaksie met die wêreld te staan, soos Swinton en Mowat (2007: 26) dit stel:

Practical Theology seeks to examine the theories and assumptions which underlie current forms of practice as well as to contribute to the development and reshaping of new theories which are then fed back into the practices of the church and world. 
Die doel van hierdie empiriese ondersoek is om op 'n wetenskaplike wyse ondersoek in te stel na die uitwerking van afwesige vaders op verskillende terreine en die mense wat die naaste aan hulle is, en ook om te bepaal watter pastorale sorg en berading noodsaaklik is om die vroue te help en gebroke gesinne en verbrokkelde huwelike te help herstel (Freeks, 2004:88-110). Die empiriese ondersoek is gedoen aan die hand van 'n kwalitatiewe ondersoek.

Volgens Struwig en Stead (2001:11-12) beskryf die term kwalitatiewe navorsing nie slegs een navorsingsmetode nie. Baie navorsingsmetodes word met kwalitatiewe navorsing geassossieer. Kwalitatiewe navorsing sluit benaderings soos fenomenologie, ekologiese sielkunde, etnografie, simboliese interaksionisme en selfs postmodernisme as 'n denkstruktuur in (vgl. ook Leedy \& Ormrod, 2005: 133-134).

Die algemene doel van kwalitatiewe navorsing is om by die oorspronklike ervarings van mense uit te kom (Silverman, 2001:13). Volgens Steyn en Lotter (2006:106; vgl. ook Gaskell, 2000:39-41) help kwalitatiewe navorsing om die leefwêreld van 'n respondent te verstaan en daarom is die werklike doel van kwalitatiewe navorsing om ' $n$ verskeidenheid opinies en verskillende weergawes van die saak te ondersoek. Volgens Denzin en Lincoln (2003:12) is kwalitatiewe navorsing 'n direkte aanslag teen die "waardevrye-objektiewe-wetenskapsmodel" en daarom is die sterk punt van kwalitatiewe navorsing die vermoë om waar te neem en te analiseer wat werklik in 'n natuurlike situasie gebeur. Steyn en Lotter (2006:107) beweer ook verder dat kwalitatiewe navorsing nuwe velde van navorsing open en dat dit nuwe perspektiewe na vore bring. Die ervaarde werklikheid van die respondente is juis die aspek waarmee kwalitatiewe navorsing werk. Kwalitatiewe navorsing gee derhalwe aan respondente die geleentheid om elkeen op sy/haar eie manier die werklikheid te beskryf (Silverman, 2001:95). Botha (2009:162) toon ook aan dat daar groot verskille is tussen die doel, die proses, data-insameling, data-analise en rapportering van bevindings wanneer die kwantitatiewe en kwalitatiewe benaderings vergelyk word (vgl. ook Snape \& Spencer, 2003:3-5).

Vir die doel van hierdie ondersoek, is vraelyste en onderhoude gebruik om die rol van die afwesige en onbetrokke vader vas te stel asook die implikasies wat dit vir die hele familiestruktuur inhou. 


\subsection{Werkswyse}

'n Steekproef is gemaak om die verloop van die uitwerking van afwesige vaders te bepaal deur onderhoude te voer met vroue wat hierdie probleem eerstehands ervaar, asook om vraelyste hieroor te laat invul.

Alhoewel hierdie navorsing primêr in die kleurlingwoongebied, Promosa, in Potchefstroom gedoen is, oordeel die navorsers dat die resultate daarvan simptomaties kan wees van 'n groter prentjie in die Suid-Afrikaanse konteks.

\subsection{Fokusgroep}

'n Fokusgroep is 'n spesifieke groep deelnemers wat deur die navorser geïdentifiseer en genader word (Kerlinger \& Lee, 2000:700702; vgl. ook Freeks, 2007:9). 'n Fokusgroep bestaan normaalweg uit ses tot twaalf persone wat deur ' $n$ fasiliteerder gelei word. In so 'n fokusgroep praat die lede vrylik en spontaan oor 'n sekere onderwerp (Krueger, 1988:56). Die doel van so 'n fokusgroep is om diepgaande gesprekke te voer en sodoende inligting te verkry rakende konsepte, persepsies en idees van aspekte wat almal in die groep raak (Leedy \& Ormrod, 2005:146). Hierdie is meer as net vraag-enantwoord interaksie. Die idee is dat lede van die groep die onderwerp onder mekaar bespreek (Struwig \& Stead, 2001:99-100). Volgens Ritchie et al. (2003:83) is kwalitatiewe steekproewe gewoonlik klein omdat dit in kwalitatiewe navorsing nie om die insidensie of voorkoms gaan nie en ook omdat die soort inligting wat kwalitatiewe navorsing lewer, gewoonlik ryk is aan besonderhede. 'n Tipiese steekproef kan tussen 5 en 25 individue beslaan (Leedy \& Ormrod, 2005:139). Janse van Rensburg (2007:6-7) dui selfs minder aan (vier tot ongeveer twintig). In hierdie geval bestaan die ondersoek- of fokusgroep uit agt vroue in Promosa in Potchefstroom.

\section{Metodologiese verantwoording van die empiriese ondersoek}

'n Ondersoekmetode is by die fokusgroep gebruik waar persoonlike onderhoude met behulp van vraelyste gevoer is (Freeks, 2004:122127). Daar is onderhoude gevoer met die genoemde agt vroue wat die dilemma van 'n afwesige vaderfiguur intens ervaar en elke dag daarmee saamleef. Die onderhoude is verder ongestruktureerd en 'n een-tot-een-metode (Neuman, 2003:344, 371-374) is gebruik. Volgens Silverman (2001:92) is onderhoude 'n ontmoeting tussen mense in 'n poging om groter begrip vir mekaar te hê. Met onderhoude 
word ook vasgestel watter verskillende menings na vore kom en sodoende word 'n oorsig verkry van die problematiek (vgl. in hierdie verband Freeks, 2007:9).

\section{Ondersoekgroep}

Uit die literatuurstudie is aangetoon watter nadelige gevolge daar voorkom wanneer die vader afwesig is. Baie gesinne het skade gely sonder die funksionering van 'n vaderfiguur. Veral by die kinders is dikwels onmeetbare letsels gelaat, omdat die vader nie sy vaderlike plig en rol behoorlik kon (of wou) vervul nie. Die literatuurstudie word in die res van die artikel "getoets" aan die praktyk waar vaders inderdaad afwesig is. Daar word dus ondersoek watter effek afwesige vaders op die gesin het.

In die ondersoek is gebruik gemaak van 'n vraelys en onderhoude. Die vrae op die vraelyste het die volgende aspekte gedek: die aard van die probleem, die impak en gevolge op kerklike denominasies asook die gemeenskap. Die steekproef vroue kom uit verskillende sosio-ekonomiese woonstrata waaronder plakkerskampe, omliggende woonbuurte en uit die hoër middelklas.

\subsection{Die proses en die beskrywing}

In die navorsingsproses is veral gekyk na aspekte soos persoonlike gegewens, huwelik/verhouding, ouerhuis, godsdiens, die pastoor/ leier/predikant se betrokkenheid by die situasie van 'n afwesige vader en die kinders se reaksie.

\subsection{Die respondente se omstandighede}

Die respondente (genoemde agt vroue) se ouderdomme wissel van 30 tot 46 jaar. Sommige van die vroue het mislukte huwelike en in ander gevalle het die mans net verdwyn. Hierdie vroue is almal woonagtig in Promosa. Vier van die vroue is getroud, een is ongetroud, twee is geskei en een is ' $n$ weduwee. Dit gee 'n goeie verspreiding van die soort verhoudings waarin die vroue staan/gestaan het.

\subsubsection{Die vraelyste het die volgende sake behels:}

\section{- $\quad$ Algemene opmerkings}

Onder algemene opmerkings het ses van die respondente aangedui dat hulle huwelike glad nie aan hulle verwagtings voldoen het nie weens die afwesigheid van die man en vader. Dit het hulle nadelig 
beïnvloed. Daarteenoor het twee van die respondente se huwelike grootliks aan hulle verwagtings voldoen. By een was die negatiewe aspek dat die vader nie kon kommunikeer nie. Hy kon nooit sê waarheen hy gaan nie en dit het die situasie vererger. By 'n ander een was die negatiewe aspek gesinsgeweld.

\section{- $\quad$ Die godsdiensaspek}

Wat die godsdiensaspek betref, het sewe respondente aangedui dat hulle "wedergebore Christene" is. Daar is een respondent wat "die pad byster geraak het" (soos sy dit gestel het). As gelowiges neem eersgenoemde respondente gebed en die bestudering van die Bybel ernstig op. Vir hulle is gebed en Bybellees van kardinale belang omdat dit hulle krag en sterkte gee in hulle benarde situasie waar die vader afwesig is.

\section{- $\quad$ Die uitwerking op die kinders}

Met betrekking tot die uitwerking op die kinders kon afgelei word dat slegs vier respondente se kinders erge haatgevoelens teenoor die vader openbaar. Die kinders is negatief beïnvloed as gevolg van die afwesige vader. By sommige van die kinders kom haatuitsprake voor soos die volgende:

"Ons haat ons pa."

"Hy is nie ons pa nie, omdat hy by 'n ander vrou gaan kuier het en hy onderhou ander kinders in plaas van sy eie."

"Hy is nie ons pa nie want hy sorg [nie vir] ons nie." (Vgl. Freeks, 2004:63.)

By die ander respondente het die vader se drankmisbruik ook haatgevoelens by die kinders veroorsaak. Alhoewel sommige respondente se kinders hulle pa baie mis as hy nie daar is nie, het hulle ook ernstige haatgevoelens teenoor hom ontwikkel wanneer hy teenwoordig is. Hy is dikwels onder die invloed van drank, raak aggressief en slaan dan die moeder. Hierdie optrede van die vader het 'n toenemende gevoel van haat by die kinders veroorsaak. Die vader se drankmisbruik, bakleiery en vloekery maak die kinders gespanne en emosioneel. Hierdie kinders is hatig en betoon geen respek teenoor hulle vader nie. Van die haatuitsprake wat voorkom, is:

"Ons het geen respek vir hom nie en ons eer hom nie." 
Die grootste rede waarom hierdie kinders negatief en hatig teenoor hulle vader is, is die feit dat hy hulle in die skande steek by hulle vriende. Die vader se onbetrokkenheid en verwaarlosing van die gesin laat die kinders baie sleg voel. Dit is vir hulle baie moeilik om in die teenwoordigheid van hulle maats en onderwysers op hulle vader trots te wees. Uitings wat soms voorkom, is:

"Ons voel skaam omdat ons 'n vader het."

"Hy is sleg en steek ons net in die skande voor ander mense."

Slegs by vier respondente se kinders word geen haatgevoelens teenoor hulle vader getoon nie. In die een respondent se geval tree die broer (ander vader) as vaderfiguur op. Hier is geen haatspraak nie, omdat die kind nog klein is. In die ander gevalle is die een seun teleurgesteld in sy vader, omdat hy nie teenwoordig en betrokke is nie. Die seun sukkel baie met sy studie en die finansiële druk is ook groot. Die ander kinders verlang baie na die vader, want hy het (voorheen) baie vir hulle beteken en dit blyk dat hulle verlang na ' $n$ vaderfiguur in hulle lewens. Sommige van die kinders het emosionele skade en vrese as gevolg van die vader se verkeerde optrede en die feit dat hy nie sy rol behoorlik vervul het nie.

Samevattend kan gesê word dat die vader in al die gevalle wat genoem is, in hulle oë gefaal het en daardeur is die meeste kinders teleurgesteld in hulle vaders.

\section{Gevolgtrekkings uit die navorsing}

In die eerste gedeelte van die artikel is aangetoon dat die geraadpleegde literatuur dit eens is dat die afwesigheid van vaders in gesinne tot verskillende sosiale, ekonomiese, emosionele en psigologiese probleme by kinders lei.

Uit die tweede gedeelte van die artikel wat handel oor die empiriese navorsing oor afwesige vaders het die volgende geblyk:

Al agt respondente beskou hulleself as wedergeborenes. Een respondent het die pad byster geraak. Van die agt respondente het net twee nie Bybelse berading ontvang nie. Geen leier of pastoor was direk by die respondente betrokke met betrekking tot die probleem van ' $n$ afwesige vader nie, behalwe in die geval van een respondent. Alhoewel godsdiens deur al agt respondente as die belangrikste element in hulle lewe beskou word, blyk dit tog dat almal Bybelse berading (en hulp van buite hulleself) benodig oor hoe God elkeen op haar eie manier help en bystaan in hulle pro- 
bleem van 'n afwesige vader. Indien die respondente vroeër effektiewe Bybelse berading sou ontvang het, kon dit waarskynlik ook 'n effek op hulle huwelike gehad het en kon hulle 'n beter kwaliteit lewe gehad het. Dit is deur die vraelyste en onderhoude duidelik dat die probleem van 'n afwesige vader wat nie sy rol en funksie behoorlik vervul het nie, ook gelei het tot egskeidings (vier respondente). Hierdie moeders ervaar en ondergaan emosionele druk, en het ' $n$ behoefte aan Bybelse berading. Volgens ander respondente se getuienis beskou hulle dit so dat God se hand ingegryp het en hulle situasie so verbeter en hulle probleme opgelos het.

\section{Aanbevelings}

Omdat die verskynsel van die afwesige vader soveel impak het, kan sekere voorstelle gemaak word vir die toerusting van vaders om hulle betrokkenheid te verhoog, en vir die begeleiding van die vroue asook die rol van die kerk in hierdie verband.

\subsection{Die toerusting van vaders}

Die vraag wat dus gevra word, is: Hoe kan die vader gehelp word om sy rol behoorlik te vervul?

Toerusting aan die vaders sal onder andere die volgende aspekte behels:

- Geloofsbegeleiding

- Sy verantwoordelikheid en aanspreeklikheid

- Hoe om sy gesag in liefde uit te leef

- Hoe hy as model vir die kinders kan optree

- Watter beskerming hy aan die gesin moet voorsien

- Watter intimiteit en liefde van hom behoort uit te gaan

- Watter leiding hy in die gesin behoort te neem

Die vader kan sy rol behoorlik vervul deur basiese beginsels na te volg en deur teenwoordig en betrokke te wees tydens die verskillende lewensfases van die kind as baba, kleuter, laerskoolkind en hoërskooltiener en deur die geloofsbegeleiding wat hy aan sy kinders gee. 


\subsection{Die begeleiding van die vrou}

Die vroue wat berading ontvang het, het weer op hulle beurt berading, advies en leiding aan ander vroue verskaf en so mekaar ondersteun in terme van die uitspraak van Paulus in 2 Korintiërs 1:4:

In elke moeilikheid help Hy ons. Daarom kan ons ook weer ander help wat in allerlei moeilikheid verkeer. Ons kan hulle bemoedig met dieselfde bemoediging waarmee God ons bemoedig het ...

Die vroue wat aan die navorsing deelgeneem het, het sterk gestaan as vroue/moeders en hulle plek in die gemeenskap volgestaan.

\subsection{Die kerk se ondersteuning}

Die kerk het berading, leiding, advies en vertroosting aangebied vir sommige van die vroue. Gebed en Bybellees was ondersteuning wat die kerk gebied het wat daadwerklik krag en sterkte gee in hulle benarde situasie. Dit is uit die navorsing duidelik dat die kerk deur die ampte, maar ook deur medegelowiges, 'n baie pertinente rol te speel het in hierdie vroue en kinders se lewens. Daar behoort strukture geskep te word waardeur voltydse berading aan gesinne met afwesige vaders gebied kan word.

\section{Samevatting}

In hierdie artikel is eers vanuit 'n literatuurstudie aangetoon wat die effek van afwesige vaders op die gesinstruktuur en veral op die kinders is. Verder is hierdie inligting geverifieer op grond van empiriese navorsing onder ' $n$ fokusgroep vroue in Promosa (Potchefstroom), deur 'n kwalitatiewe ondersoek na die rol van afwesige vaders. Die verskillende fasette waarna gekyk is, was persoonlike gegewens, huwelik/verhouding, ouerhuis, godsdiens, die pastoor/ leier/predikant se betrokkenheid by die vroue se situasie en die reaksie van die kinders van die respondente op die omstandighede. Dit was 'n poging om hierdie vroue se omstandighede (die vader wat afwesig is) beter te begryp en hulle te begelei. Gevolgtrekkings is uit die navorsing gemaak en daar is beskryf hoe die vader se rol moet lyk. Die artikel word afgesluit met aanbevelings hoe die vader sy rol na behore kan vervul met betrekking tot die geloofslewe van die kind as baba, kleuter, laerskoolkind en tiener. Ten slotte word daar ook kortliks aandag gegee aan die kwaliteite en rolvervulling van die vader soos aanspreeklikheid, verantwoordelikheid, gesag en modellering. Hierdie empiriese navorsing kan aanleiding gee tot verdere navorsing oor die problematiek van afwesige vaders, ook vir die 
vakgebied van die Praktiese Teologie. Dit het ook belangrike implikasies vir berading en pastorale begeleiding van huwelike, verhoudings en kinders wat ly as gevolg van afwesige vaders.

\section{Geraadpleegde bronne}

ANON. 1998. Fathers are important: you and your pre-schooler. Pace: 36, May.

BALLARD, P. \& PRITCHARD, J. 2001. Practical theology in action - Christian thinking in the service of church and society. London: SPCK.

BARKER, P.M. 2000. Soul man. The journal of pastoral care, 54(2):195-196.

BENGHIAT, L. 2001. Ons kinders is opgebruik. Insig, 10(2):64, Jun.

BOTHA, J.U. 2009. Theophostic Prayer Ministry (TPM): 'n prakties-teologiese beoordeling. Potchefstroom: Noordwes-Universiteit. (Ph.D.-proefskrif.)

CAMBELL, C. 1994. Township families and youth identity. Pretoria: HSRC.

CARTLEDGE, M.J. 2003. Practical theology - charismatic and empirical perspectives. London: Paternoster.

DENZIN, N.K. \& LINCOLN, Y.S. 2003. The discipline and practice of qualitative research. (In Denzin, N.K. \& Lincoln, Y.S. The landscape of qualitative research. 2nd ed. Thousand Oaks: SAGE. p. 1-45.)

DICKIE, J., LINDSEY, V.A., KOBYLAK, J.R. \& NIXON, K.M. 2006. Mother, father, and self: sources of young adults' God concepts. Journal of scientific religion, 45(1):57-71.

FAMILY LIFE. 1998. A declaration of timeless values. htt://www.familylife. org.za/manifesto.html Date of access: 2 Nov. 2001.

FORD, J., NALBONE, D.P., WETCHER, J.L. \& SUTTON, P.M. 2008. Fatherhood: how differentiation and identity status affect attachment to children. American journal of family therapy, 36(4):284-299.

FREEKS, F.E. 2004. Die rol van die ontbrekende vaderfiguur in die SuidAfrikaanse konteks: 'n prakties-teologiese studie. Potchefstroom: PU vir CHO. (M.A.-verhandeling.)

FREEKS, F.E. 2007. 'n Karakterbouprogram vir verdere onderwys en Opleidingskolleges. Potchefstroom: Noordwes-Universiteit. (Ph.D.-proefskrif.)

GASKELL, G. 2000. Individual and group interviewing: qualitative researching with text, image and sound. London: SAGE.

GOEKE-MOREY, M. \& CUMMINGS, E.M. 2007. Impact of father involvement: a closer look at indirect effects models involving marriage and child adjustment. Applied developmental science, 11(4):221-225.

GRAINGER, S. 2004. Family background and female sexual behaviour: a test of the father-absence theory in Merseyside. Human nature, 15(2):133-145.

HEYNS, L.M. \& PIETERSE, H.J.C. 1998. Eerste treë in die praktiese teologie. Pretoria: Gnosis.

JANSE VAN RENSBURG, J. 2007. Navorsingsmetodologie. Ongepubliseerde notas vir 'n werkswinkel by die Fakulteit Teologie van die NWU se Potchefstroomkampus, 9 Maart 2007.

JOHNSON, W.B. 1993. Father uninvolvement. Journal of psychology and Christianity, 12:301-311.

KERLINGER, F.N. \& LEE, H.B. 2000. Foundations of behavioural research. 4th ed. California: Harcourt College Publishers. 
KÖSTENBERGER, A. 2003. Marriage and family in the New Testament. (In Campbell, K.M., ed. Marriage and family in the Biblical world. Downers Grove: InterVarsity. p. 240-284.)

KRAMPE, E.M. \& NEWTON, R.R. 2006. The father presence questionnaire: a new look measure of the subjective experience of being fathered. $A$ journal of theory, research and practice about men as fathers, 4(2):159190.

KRUEGER, R.A. 1988. Focus groups: a practical guide for applied research. Newbury Park: SAGE.

LEEDY, P.D. \& ORMROD, J.E. 2005. Practical research: planning and design. 8th ed. Upper Saddle River: Pearson Merrill Prentice Hall.

LOUW, P.L. \& NIDA, E.A. 1989. Greek-English Lexicon of the New Testament based on semantic domains. Vol. 1 \& 2. New York: Bybelgenootskap van Suid-Afrika.

LUPTON, D. \& BARCLAY, L. 1997. Constructing fatherhood: discourses and experiences. London: SAGE.

MANDARA, J., MURRAY, C.B. \& JOYNER, T.N. 2005. The impact of fathers' absence on African American adolescents' gender role development. Sex roles, 53(3 \& 4):207-220.

MOXNES, H. 1997. What is family? Problems in constructing early Christian families. (In Moxnes, H., ed. Constructing early Christian families: family as social reality and metaphor. London: Routledge. p. 13-41.)

NEUMAN, W.L. 2003. Social research methods: qualitative and quantitative approaches. Boston: Allyn \& Bacon.

NHLAPO, R.T. 1998. Harmonisation of the common law and indigenous law. South African Law Commission Act, 1973 (Act 19 of 1973), 9 May. Pretoria: South African Law Commission.

NISKANEN, P. 2006. Yhwh as Father, Redeemer, and Potter in Isaiah 63:764:11. Catholic Biblical quarterly, 68(3):397-407.

OLIVIER, M.A.J. 1997. 'n Perspektief op opvoeding in die enkelouergesin. Die Unie, 94(2):19-22.

OLSEN, S. 2007. Daddy's come home: evangelicalism, fatherhood and lessons for boys in late nineteenth-century Britain. Fathering, 5(3):174-196.

PALKOVITZ, R. 2007. Challenges to modelling dynamics in developing a developmental understanding of father-child relationships. Applied developmental science, 11(4):190-195.

RITCHIE, J., LEWIS, J. \& ELAM, G. 2003. Designing and selecting samples. (In Richie, J. \& Lewis, J., eds. Qualitative research practice: a guide for social science students and researchers. London: SAGE. p. 77-108.)

SEUTTER, R.A. \& ROVERS, M. 2004. Emotionally absent fathers: furthering the understanding of homosexuality. Journal of psychology and theology, 32(1):43-49.

SILVERMAN, D. 2001. Interpreting qualitative data. 2nd ed. London: SAGE.

SMIT, R. 2004. Involved fathering: expanding conceptualisations of men's paternal caring. Koers, 69(1):101-120.

SNAPE, D. \& SPENCER, L. 2003. The foundations of qualitative research. (In Richie, J. \& Lewis, J., eds. Qualitative research practice: a guide for social science students and researchers. London: SAGE. p. 1-23.)

STAPLES, R. 1999. The black family. Belmont: Wadsworth.

STEYN, A.F. 1993. Family structures in the R.S.A. Pretoria: HSRC. 
STEYN, R.S. \& LOTTER, G.A. 2006. Voorhuwelikse verhoudings: 'n verkennende kwalitatiewe empiriese ondersoek. Praktiese teologie in Suid-Afrika, 21(1):104-120.

STRUWIG, F.W. \& STEAD, G.B. 2001. Planning, designing and reporting research. Cape Town: Longman.

SWINTON, J. \& MOWAT, H. 2007. Practical theology and qualitative research. London: SCM.

THOMAS, A.J. 2008. Empirical theology, African Pentecostals and an "Evangelical-charismatic hermeneutic". Practical theology in South Africa, 23(3):46-66.

VAN DER VEN, J. 1993. Practical theology: an empirical approach. Kampen: Kok.

VAN DER VEN, J.A. 1994. Empirical methodology in practical theology: why and how? Practical theology in South Africa, 9(1):29-44.

VOGEL, C.A., BRADLEY, R.H., RAIKES, H.H., BOLLER, K. \& SHEARS, J.K. 2006. Relation between father connectedness and child outcomes. Parenting: science and practice, 6(2 \& 3):189-209.

WALL, J. 2007. Fatherhood, childism, and the creation of society. Journal of the American academy of religion, 75(1):52-76.

WALTKE, B.J. 2001. Genesis: a commentary. Grand Rapids: Zondervan.

WARREN, R.C. 2005. Our fathers who are on earth: if Satan thinks they are a key battleground, shouldn't we? Christianity today, 49(5):53.

WILLIAMS, A. 2008. We badly need good fathers. Human events, 64(21):18.

\section{Kernbegrippe:}

afwesige vaders

kwalitatiewe ondersoek

praktiese teologie

Promosa gemeenskap

Key concepts:

absent fathers

practical theology

Promosa community

qualitative research 